\title{
Impact of Environmental Investment on Financial Performance: Evidence from Chinese Listed Companies
}

\author{
Zhenji Jin, Jian Xu* \\ School of Management, Qingdao Agricultural University, Qingdao 266109, China
}

Received: 7 May 2019

Accepted: 24 July 2019

\begin{abstract}
Using the data of Chinese listed companies during 2012-2016, this study examines the effect of environmental investment on financial performance, as measured by return on assets (ROA). We also examine the moderating effect of industry attributes, company ownership, and region on this relationship. The empirical results show that there exists a U-shaped relationship between environmental investment and financial performance. However, only $11 \%$ of Chinese listed companies can attain profitable environmental investment. In addition, the impact of environmental investment on financial performance in state-owned enterprises (SOEs) is higher than that in private-owned enterprises (POEs), and a company's environmental investment in China's eastern regions can do more to promote financial performance. The findings of this study can help managers to reasonably manage the tensions between environmental investment in relation to stakeholders and the pursuit of profitability.
\end{abstract}

Keywords: environmental investment, financial performance, Chinese listed companies

\section{Introduction}

The issue about environmental effects and economic or financial performance has attracted a large managerial and academic attention [1-7]. With the introduction of the concept of sustainable development, environmental protection has become an important issue in the process of economic development. It is generally accepted that economic development brings not only prosperity but also environmental destruction to nations [8]. However, the cost of environmental pollution for economic development is not sustained.

*e-mail: xujiansword@163.com
With the rapid development of China's economy, environmental problems have become increasingly serious [9, 10]. In 2015, China became the world's largest emitter of carbon dioxide $\left(\mathrm{CO}_{2}\right)$ and sulfur dioxide $\left(\mathrm{SO}_{2}\right)$ emissions [11]. The Chinese government has transferred the pattern of economic development from high-speed to high-quality growth. In addition, the government advocates harmonious coexistence between humans and nature, and sticks to the path of green and sustainable development [12]. In 2018, Chinese president Xi Jinping said that "lucid waters and lush mountains are invaluable assets" in the Eco Forum Global Annual Conference held in Guiyang. In recent years, the Chinese government has invested a huge amount of money in environmental protection [13]. From 2012 to 2016, total investment in treatment of environmental 


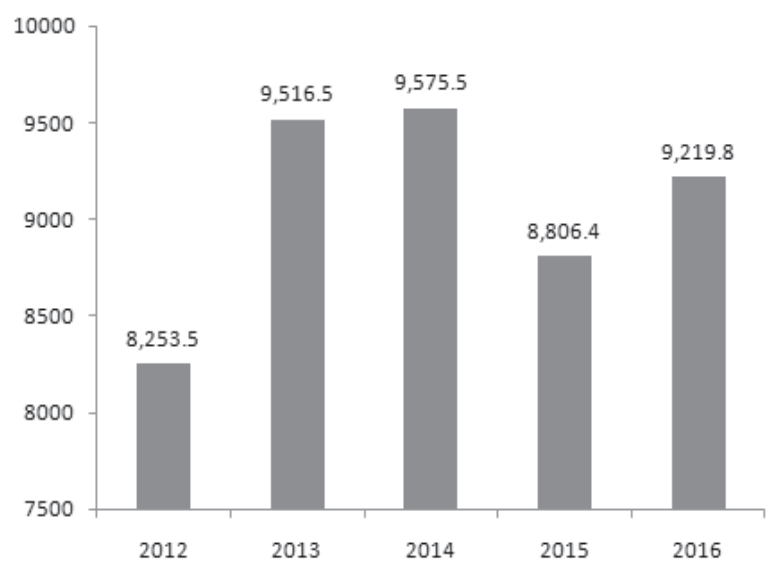

Fig. 1. Total investment in treatment of environmental pollution in China from 2012 to 2016 (billion yuan).

pollution reached about 9000 billion yuan annually (Fig. 1). Lin et al. [14] and Li et al. [15] also confirmed that environmental protection investment has a positive effect on China's GDP growth.

Environmental issues cannot be ignored by any responsible company. Companies, the main body of environmental protection, currently are facing a growing demand from society for environmental protection. The environment is a key requirement for any company to achieve long-term success $[16,17]$. The solution to environmental problems depends largely on environmental investment. Guided by Lundgren and Zhou [18], we define environmental investment as a company's efforts to reduce its environmental impact. This study focuses on Chinese listed companies because China highly values ecological and environmental protection. Environmental investment of Chinese listed companies aims at conserving resources and reducing the environmental burden.

Understanding the relationship between environmental investment and financial performance is of increasing interest to both stakeholders and regulators. If this relationship is positive, it will encourage companies to improve environmental performance without necessary environmental regulation. Thus, the purpose of this study is to investigate whether environmental investment of Chinese listed companies has influenced their financial performance. Also, we examine the moderating effect of industry attribute, company ownership, and region on this relationship.

This paper contributes to the extant literature as follows. First, most studies have focused on developed countries such as the USA, Japan and France, while little has been done in developing countries such as China. Our study aims to expand the literature on environmental investment and financial performance. In addition, a majority of studies do not consider the moderating effect of industry attributes, company ownership and region on this relationship. Second, our study contributes to the area of environmental studies using firm-level data. Previous research, such as Klassen and McLaughlin [19], King and Lenox [20], Al-Tuwaijri et al. [21], and Tamazian et al. [22], has focused on the industrial level. Finally, this study can enable corporate management to make reasonable investment decisions on ecological protection by the understanding of this relationship. It also will help regulators concentrate their monitoring efforts on firms with a weak correlation between environmental and financial performance.

\section{Literature Review and Hypotheses Development}

The relationship between environmental investment and financial performance is still inconsistent in academia.

The traditional theory states that environmental investment is a costly burden for firms, which is likely to reduce their profitability [23]. Because environmental protection requires additional investments in a nonproductive sector that are not directly related to financial performance, traditionalists suggest a trade-off relationship between them. For example, if a company wants to increase the production output for profit, the production increase is often related to ecological problems. In this situation, the firm faces a critical tradeoff: incurring the cost of investment in environmental protection vs. benefiting from environmental investment [24]. Orsato [25] pointed out that corporate environmental protection requires a large amount of money to purchase environmental equipment and develop new environmental technology, which increases operating costs. Taking U.S. electric utility firms as the research sample, Sueyoshi and Goto [26] confirmed that environmental protection expenditure under the U.S. Clean Air Act decreases firms' financial performance, measured by return on assets (ROA). Horváthová [3] reported a negative link between environmental and financial performance. Wang and Zhang [10], based on the data of China's manufacturing listed companies during 2009-2013, found that corporate environmental investment is negatively correlated with financial performance (measured through ROA). Based on the data of 79 companies in the heavy chemical industry, Huang [27] found that the investment in environmental protection has a negative impact on short-term financial performance. Recently, Lu and Taylor [28] used the data from Newsweek magazine's green rankings to measure the association between environmental performance, environmental disclosure, and financial performance. Their results showed a negative relationship between environmental performance and financial performance.

Some scholars who challenge this trade-off relationship pointed out that strengthening environmental investment is positively related to financial performance. On the one hand, this is because environmental expenditure can be considered an investment in innovative new technology that reduces pollution 
abatement costs, thus improving firm performance [29-31]. On the other hand, from the income perspective, McGuire et al. [32] has suggested that environmental management behavior can establish a good corporate image and gain consumer loyalty, which indirectly improves company revenue. An early study conducted by Bragdon and Marlin [33] found that a firm's profitability (earnings per share and return on equity) increases when environmental performance improves. Klassen and McLaughlin [19] discussed that environmental management has a positive linkage to firm performance by improving operating income and reducing product costs. Using a sample of S\&P 500 companies, Waddock and Graves [34] found a positive relationship between corporate environmental management and financial performance (measured through ROA). Esty and Porter [35] concluded that industrial ecology can help managers find inside and outside opportunities to add value to their products or cut their costs. Based on the data of 652 U.S. manufacturing firms, King and Lenox [20] found a linkage between lower pollution and higher Tobin's q ratio. Al-Tuwaijri et al. [21] also argued that firms could make a win-win situation with environmental protection. Ambec and Lanoie [2] listed seven channels through which environmental practices may increase their revenue or reduce their costs: (1) better access to certain markets; (2) differentiating products; (3) selling pollution-control technology; (4) risk management and relations with external stakeholders; (5) cost of material, energy, and services; (6) cost of capital; and (7) cost of labor. Bagur-Femenías et al. [36] pointed out that the adoption of environmental management practices directly impacts the economic results of small service businesses. Analyzing the data of Chinese listed companies, Song and Zhao [30] concluded that environmental management behaviors can improve corporate value. More recently, Peng and Yue [37] found a positive correlation between corporate environmental investment and financial performance of companies in the papermaking and printing industry. Nishitani et al.'s [38] findings showed that Indonesian firms that reduce greenhouse gas emissions are more likely to enhance profit further. Masocha [39] also found that environmental sustainability practices can contribute to ecological and social performance.

Interestingly, some studies have suggested a nonlinear correlation between them. For example, based on 17 firms in the paper and pulp industry, Bowman and Haire [40] found that middle performers with regard to pollution control have a higher return on equity than low or high performers. Fujii et al. [41], based on the data of Japanese manufacturing firms, demonstrated an inverted U-shaped relationship between ROA and environmental performance calculated by aggregated toxic risk. Pekovic et al. also [8] used the data of more than 6,000 French firms over a 5-year period and found that the impact of environmental investment on economic performance, measured by net profits, follows an almost U-inverted curve. However, using
China's A-share listed companies as the sample, Gao [42] found that environmental protection investment has a U-shaped relationship with enterprise market value (measured through ROA and market-to-book ratio). Therefore, we propose the following hypothesis:

Hypothesis 1 (H1). Environmental investment has a non-linear relationship with financial performance.

Companies' investment decision-making is inevitably influenced by industry environment and industry attributes [43]. Different industries with different market environments and government regulation intensities usually lead to differences in market competition and firm performance. Heavy-polluting industries face more stringent environmental regulation and bear more social and environmental responsibility than other industries, which enables them to invest more in the purchase of environmental protection facilities, the improvement of environmental protection technology, and the treatment of pollutant emissions [44, 45]. The findings of Tang et al. [46] showed that heavy-polluting companies invest more in environmental protection than non-heavypolluting ones. That is, compared with non-heavypolluting companies, heavy-polluting companies are more sensitive to environmental expenditure. Therefore, we propose the following hypothesis:

Hypothesis 2 (H2). Industry attribute has a moderating effect on the non-linear relationship between environmental investment and financial performance.

Compared with private-owned enterprises (POEs), state-owned enterprises (SOEs) are under greater pressure from the government and the public, and are more likely to implement proactive environmental strategies, which in turn has an important impact on a company's environmental behaviors. For example, Montabon et al. [47] found that environmental performance can lead to good financial performance when the enterprises implement proactive environmental management. Therefore, SOEs should have better environmental performance than POEs, and have a higher level of environmental information disclosure. On the other hand, the influence of company ownership on financial performance has always been a hot issue in the field of management. Scholars [48-50] have argued that SOEs have strong ties with the government, and most SOE executives are directly appointed by the government. Under transitional economy conditions, it is easier for SOEs to obtain heterogeneous resources through such a close relationship, which can promote the financial performance of SOEs. However, POEs need to pay a lot through rent-seeking behaviors to establish political connections, which obviously affects their financial performance. Thus, SOEs are more likely to have better financial performance than POEs. However, Deng and Zeng [51] found that the operational efficiency of SOEs is lower than that of POEs. Therefore, we propose the following hypothesis:

Hypothesis 3 (H3). Company ownership has a moderating effect on the non-linear relationship between environmental investment and financial performance. 
The government implements different environmental protection policies for companies in different regions. For companies in developed regions, the government focuses on corporate environmental protection behaviors rather than the improvement of their economic performance. Meanwhile, the assessment of environmental performance has become an important performance standard for Chinese listed companies. Conversely, for companies in less developed regions, the responsibility of the government is to promote local economic development and solve people's living problems. Under such circumstances, companies generally lack environmental awareness, which tends to result in poor environment and heavy pollution.

On the other hand, companies in developed regions usually enjoy faster growth and stronger capabilities of technological innovation. They often invest more in environmental protection, respond to government environmental policies, and reduce the waste of resources. In less developed regions, companies may not be able to quickly acquire advanced production technologies. In addition, managers of companies in less developed regions may lack the understanding of environmental issues and need to pay a large amount of money for environmental protection, which affects the financial performance of these companies.

$\mathrm{Li}$ [52], based on the data of environmental performance of listed companies in China's extractive industries, found that environmental performance of companies in first- and second-tier cities is greater than that of companies in third- and fourth-tier cities. Yang and Wang [53] also found that the positive impact of environmental performance on financial performance of companies in China's eastern regions is greater. Zhang [54] pointed out that the impact of corporate environmental performance on financial performance is more pronounced in developed areas than in developing areas. Thus, hypothesis 4 is proposed as follows:

Hypothesis 4 (H4). Region has a moderating effect on the non-linear relationship between environmental investment and financial performance.

\section{Materials and Methods}

\section{Sample Selection}

We selected all companies listed on the Shanghai and Shenzhen Stock Exchanges during 2012-2016. We deleted companies that do not disclose environmental expenditure in their financial statements, companies with a debt ratio greater than 1, companies with missing information, and special treatment companies. After winsorizing the variables at $1 \%$ and $99 \%$, our final sample consisted of 455 firm-year observations for 212 companies. Environmental expenditure information is derived from the Rankins CSR Ratings (RKS) database, and other data are sourced from the China Stock Market and Accounting Research
(CSMAR) database. The regressions are carried out using SPSS version 20.

\section{Variables}

(1) Dependent variable. Guided by the literature $[10,26,34,41,42,55-59]$, ROA is used to measure financial performance in this study. ROA, a measure of a company's efficiency in utilizing total assets, is measured by dividing net income by average total assets.

(2) Independent variable. Guided by the literature [7, $10,46,60]$, environmental investment (EI) is measured by dividing environmental expenditure to total assets. This measure is more immediate and tangible for firms. Environmental investment includes the following seven categories: expenditure on environmental technology research and development and reconstruction, expenditure on environmental facilities and systems and reconstruction, expenditure on pollution control, expenditure on clean production, environmental taxes, expenditure on ecological protection and other environmental investments.

(3) Dummy variables. Industry attribute (INDUS) is used as a dummy variable with a value of 1 if the company belongs to heavy-polluted industries and 0 if it is not. According to the Environmental Information Disclosure Guidelines for Listed Companies in China, the heavy-polluted industries include 16 sub-industries: thermal power, steel, cement, electrolytic aluminum, coal, metallurgical, chemical, petrochemical, building materials, paper, brewing, pharmaceutical, fermentation, textile, leather, and mining.

Company ownership (OWN) is used as a dummy variable with a value of 1 if the company is an SOE and 0 if it is not.

Region (AREA) is used as a dummy variable with a value of 1 if the company locates in eastern regions of China and 0 if it is not. China's eastern regions include Beijing, Tianjin, Hebei, Liaoning, Shanghai, Jiangsu, Zhejiang, Fujian, Shandong, Guangdong, and Hainan; the central regions are Shanxi, Jilin, Heilongjiang, Anhui, Jiangxi, Henan, Hubei, and Hunan; and the western regions are Inner Mongolia, Guangxi, Chongqing, Sichuan, Guizhou, Yunnan, Shaanxi, Gansu, Qinghai, Ningxia, Xinjiang, and Tibet.

(4) Control variables. Firm size (SIZE), debt ratio (LEV), R\&D intensity (RD), sales growth rate (GROWTH), and capital intensity (CAPITAL) are used as control variables. Empirical evidence [10, 38, 42] shows that firm size (SIZE) has a positive impact on firm performance. Firms with high debt ratios are more likely to have high financial risks, which is likely to reduce profits [42, 61]. Wang and Zhang [10] found that sales growth rate can positively affect financial performance of Chinese manufacturing listed companies. CAPITAL is used to control how a firm relies on capital investment. In general, high capitalintensive firms tend to pay lower labor costs than laborintensive counterparts, which contributes to better 
Table 1. Definitions of variables.

\begin{tabular}{|c|c|}
\hline Variable & Definition \\
\hline ROA & Return on assets of the company \\
\hline EI & Ratio of environmental expenditure to total assets \\
\hline EI ${ }^{2}$ & Square of the ratio of environmental investment to total assets \\
\hline INDUS & Dummy variable that takes 1 if the company belongs to heavy-polluted industries, 0 otherwise \\
\hline OWN & Dummy variable that takes 1 if the company is a SOE, 0 otherwise \\
\hline AREA & Rumple that takes 1 if the company locates in China's eastern regions, 0 otherwise \\
\hline SIZE & Ratio of total liabilities to total assets \\
\hline LEV & Ratio of R\&D expenditure to total assets \\
\hline RD & Sales growth rate \\
\hline GROWTH & Ratio of total assets to sales revenue \\
\hline CAPITAL & Dummy variable that takes 1 for the test year, and 0 otherwise \\
\hline YEAR &
\end{tabular}

performance of capital-intensive firms. Nunes et al. [62] found that R\&D intensity restricts the growth of high-tech SMEs at lower levels of R\&D intensity and improves their growth at higher levels. Finally, a year dummy is introduced in the research models.

Table 1 presents the definitions of the variables.

\section{Models}

Model (1) is used to examine the relationship between environmental investment and financial performance.

$$
\begin{aligned}
& \mathrm{ROA}_{\mathrm{i}, \mathrm{t}}=\beta_{0}+\beta_{1} \mathrm{EI}_{\mathrm{i}, \mathrm{t}}+\beta_{2} \mathrm{EI}_{\mathrm{i}, \mathrm{t}}^{2}+\beta_{3} \mathrm{SIZE}_{\mathrm{i}, \mathrm{t}} \\
& +\beta_{4} \mathrm{LEV}_{\mathrm{i}, \mathrm{t}}+\beta_{5} \mathrm{RD}_{\mathrm{i}, \mathrm{t}}+\beta_{6} \mathrm{GROWTH}_{\mathrm{i}, \mathrm{t}} \\
& +\beta_{7} \mathrm{CAPITAL}_{\mathrm{i}, \mathrm{t}}+\mathrm{YEAR}_{\mathrm{i}, \mathrm{t}}+\varepsilon_{\mathrm{i}, \mathrm{t}}
\end{aligned}
$$

Model (2), introducing the variable INDUS, is utilized to test the second hypothesis. If H2 is accepted, we expect that the coefficient on INDUS*EI ${ }^{2}$ is significant.

$$
\begin{gathered}
\operatorname{ROA}_{\mathrm{i}, \mathrm{t}}=\beta_{0}+\beta_{1} \mathrm{EI}_{\mathrm{i}, \mathrm{t}}+\beta_{2} \mathrm{EI}_{\mathrm{i}, \mathrm{t}}^{2}+\beta_{3} \mathrm{INDUS}_{\mathrm{i}, \mathrm{t}}+ \\
\beta_{4} \mathrm{INDUS}_{\mathrm{i}, \mathrm{t}} \mathrm{EI}^{2}{ }_{\mathrm{i}, \mathrm{t}}+\beta_{5} \mathrm{SIZE}_{\mathrm{i}, \mathrm{t}}+\beta_{6} \mathrm{LEV}_{\mathrm{i}, \mathrm{t}}+\beta_{7} \mathrm{RD}_{\mathrm{i}, \mathrm{t}} \\
+\beta_{8} \text { GROWTH }^{\mathrm{i}, \mathrm{t}}+\beta_{9} \mathrm{CAPITAL}_{\mathrm{i}, \mathrm{t}}+\mathrm{YEAR}_{\mathrm{i}, \mathrm{t}}+\varepsilon_{\mathrm{i}, \mathrm{t}}
\end{gathered}
$$

Model (3) introduces the variable OWN and is utilized to test $\mathrm{H} 3$. If $\mathrm{H} 3$ is accepted, we expect that the coefficient on $\mathrm{OWN}^{*} \mathrm{EI}^{2}$ is significant.

$$
\begin{gathered}
\mathrm{ROA}_{\mathrm{i}, \mathrm{t}}=\beta_{0}+\beta_{1} \mathrm{EI}_{\mathrm{i}, \mathrm{t}}+\beta_{2} \mathrm{EI}_{\mathrm{i}, \mathrm{t}}^{2}+\beta_{3} \mathrm{OWN}_{\mathrm{i}, \mathrm{t}}+ \\
\beta_{4} \mathrm{OWN}_{\mathrm{i}, \mathrm{t}} \mathrm{EI}^{2}{ }_{\mathrm{i}, \mathrm{t}}+\beta_{5} \mathrm{SIZE}_{\mathrm{i}, \mathrm{t}}+\beta_{6} \mathrm{LEV}_{\mathrm{i}, \mathrm{t}}+\beta_{7} \mathrm{RD}_{\mathrm{i}, \mathrm{t}}+ \\
\beta_{8} \mathrm{GROWTH}_{\mathrm{i}, \mathrm{t}}+\beta_{9} \mathrm{CAPITAL}_{\mathrm{i}, \mathrm{t}}+\mathrm{YEAR}_{\mathrm{i}, \mathrm{t}}+\varepsilon_{\mathrm{i}, \mathrm{t}}
\end{gathered}
$$

Introducing the variable AREA, model (4) is utilized to test the fourth hypothesis. If $\mathrm{H} 4$ is accepted, we expect that the coefficient on $\mathrm{AREA}^{*} \mathrm{EI}^{2}$ is statistically significant.

$$
\begin{aligned}
& \text { ROA }_{\mathrm{i}, \mathrm{t}}=\beta_{0}+\beta_{1} \mathrm{EI}_{\mathrm{i}, \mathrm{t}}+\beta_{2} \mathrm{EI}^{2}+\beta_{\mathrm{i}, \mathrm{t}} \mathrm{AREA}_{\mathrm{i}, \mathrm{t}} \\
& +\beta_{4} \mathrm{AREA}_{\mathrm{i}, \mathrm{t}} * \mathrm{EI}_{\mathrm{i}, \mathrm{t}}^{2}+\beta_{5} \mathrm{SIZE}_{\mathrm{i}, \mathrm{t}}+\beta_{6} \mathrm{LEV}_{\mathrm{i}, \mathrm{t}}+\beta_{7} \mathrm{RD}_{\mathrm{i}, \mathrm{t}} \\
& +\beta_{8} \mathrm{GROWTH}_{\mathrm{i}, \mathrm{t}}+\beta_{9} \mathrm{CAPITAL}_{\mathrm{i}, \mathrm{t}}+\mathrm{YEAR}_{\mathrm{i}, \mathrm{t}}+\varepsilon_{\mathrm{i}, \mathrm{t}}
\end{aligned}
$$

...where $i=1, \ldots n$ and $t=1, \ldots t$ represent the firm and year, respectively; $\beta_{0}, \beta_{1}, \beta_{2}, \beta_{3}, \beta_{4}, \beta_{5}, \beta_{6}, \beta_{7}, \beta_{8}$ and $\beta_{9}$ are the presumed parameters; and $\varepsilon$ denotes the measurement error term.

\section{Results and Discussion}

\section{Descriptive Statistics}

Descriptive statistics are shown in Table 2. The mean value of ROA is 0.0369 with the maximum value of 0.3989 and the minimum value of -0.2495 , which indicates that there may exist great differences in the firms' performance in China. The mean value of EI is 0.0055 , indicating that environmental investment level is very low. This is consistent with Wang and Zhang's [10] and Tang and Li's [44] findings. The mean value of INDUS confirms that about $65 \%$ of our sample consists of heavy-polluting companies. The mean values of OWN and AREA indicate that about $76 \%$ of our sample belongs to SOEs and about $62 \%$ are located in developed regions. In addition, the mean values of SIZE, LEV, RD, GROWTH, and CAPITAL are 23.4717, 0.5163, 0.0133, 0.2000 , and 2.1517 , respectively. 
Table 2. Descriptive statistics of full sample.

\begin{tabular}{|c|c|c|c|c|c|}
\hline Variable & $\mathrm{N}$ & Mean & Max & Min & Standard Deviation \\
\hline ROA & 455 & 0.0369 & 0.3989 & -0.2495 & 0.0575 \\
\hline EI & 455 & 0.0055 & 0.0793 & 0.000005 & 0.0093 \\
\hline INDUS & 455 & 0.65 & 1 & 0 & 0.4787 \\
\hline OWN & 455 & 0.76 & 1 & 0 & 0.4299 \\
\hline AREA & 455 & 0.62 & 1 & 0 & 0.4854 \\
\hline SIZE & 455 & 23.4717 & 28.5040 & 19.1979 & 1.5066 \\
\hline LEV & 455 & 0.5163 & 0.9523 & 0.0848 & 0.2023 \\
\hline RD & 455 & 0.0133 & 0.0870 & 0 & 0.0150 \\
\hline GROWTH & 455 & 0.2000 & 5.5441 & -0.5393 & 0.5057 \\
\hline CAPITAL & 455 & 2.1517 & 16.8758 & 0.1163 & 1.7810 \\
\hline
\end{tabular}

Table 3 demonstrates the means of the variables under different industry attributes. We find that, on average, the performance of non-heavy-polluting companies is better than heavy-polluting companies. Heavy-polluting companies invest, on average, more in environmental protection than non-heavy-polluting companies. However, in terms of EI, the results show that there is no significant difference between heavycompanies and non-heavy-polluting companies under $5 \%$ of the significance level $(\mathrm{t}=2.015)$. We also found that heavy-polluting companies, on average, have more debt and less capital intensity, and invest less in technology innovation than non-heavy-polluting companies.

Table 4 shows the means of the variables under different company ownership. We find that POEs invest, on average, more in environmental protection than SOEs, and there exists significant difference between SOEs and POEs.

Table 3. Descriptive statistics by industry.

\begin{tabular}{|c|c|c|c|}
\hline $\begin{array}{c}\text { Variable } \\
\text { (Mean) }\end{array}$ & INDUS $=1$ & INDUS $=0$ & $\begin{array}{c}\text { Difference } \\
t \text {-Statistics }\end{array}$ \\
\hline ROA & 0.0320 & 0.0459 & $-2.477^{* * *}$ \\
\hline EI & 0.0062 & 0.0043 & 2.015 \\
\hline OWN & 0.75 & 0.77 & -0.519 \\
\hline AREA & 0.55 & 0.75 & $-4.080^{* * *}$ \\
\hline SIZE & 23.4777 & 23.4606 & 0.115 \\
\hline LEV & 0.5256 & 0.4993 & $1.327^{* *}$ \\
\hline RD & 0.0117 & 0.0161 & $-3.025^{* * *}$ \\
\hline GROWTH & 0.1938 & 0.2112 & -0.351 \\
\hline CAPITAL & 1.850 & 2.7031 & $-5.016^{* * *}$ \\
\hline N & 294 & 161 & - \\
\hline
\end{tabular}

Notes: $* * p<0.05, * * * p<0.01$.
Table 5 shows the means of the variables under different regions. We find that companies in central and western regions tend to make more investments in environmental protection than companies in eastern regions.

\section{Correlation Analysis}

Table 6 represents Pearson's correlation coefficient analysis. We also compute the variance inflation factors (VIFs) and find the values of the VIFs to be less than 7 , which indicates that multi-collinearity is not a major issue in our study.

\section{Regression Results}

Table 7 presents the regression results of models (1) and (2). In model (1), the coefficient on EI is negative $(\beta=-1.203, \mathrm{t}=-2.402)$ and the coefficient on $\mathrm{EI}^{2}$ is positive $(\beta=45.222, \mathrm{t}=4.852)$, which

Table 4. Descriptive statistics by ownership.

\begin{tabular}{|c|c|c|c|}
\hline $\begin{array}{c}\text { Variable } \\
(\text { Mean })\end{array}$ & OWN $=1$ & OWN $=0$ & $\begin{array}{c}\text { Difference } \\
t \text {-Statistics }\end{array}$ \\
\hline ROA & 0.0300 & 0.0584 & -4.620 \\
\hline EI & 0.0081 & 0.0120 & $-3.126^{* * *}$ \\
\hline INDUS & 0.64 & 0.67 & -0.519 \\
\hline AREA & 0.58 & 0.75 & $-3.170^{* * *}$ \\
\hline SIZE & 23.7441 & 22.6272 & 7.157 \\
\hline LEV & 0.5416 & 0.4377 & 4.819 \\
\hline RD & 0.0117 & 0.0181 & $-3.979 * *$ \\
\hline GROWTH & 0.1880 & 0.2371 & -0.890 \\
\hline CAPITAL & 2.1181 & 2.2558 & -0.708 \\
\hline N & 344 & 111 & - \\
\hline
\end{tabular}

Notes: $* * p<0.05, * * * p<0.01$ 
Table 5. Descriptive statistics by region.

\begin{tabular}{|c|c|c|c|}
\hline $\begin{array}{c}\text { Variable } \\
(\text { Mean })\end{array}$ & AREA $=1$ & AREA $=0$ & $\begin{array}{c}\text { Difference } \\
t \text {-Statistics }\end{array}$ \\
\hline ROA & 0.0442 & 0.0249 & 3.522 \\
\hline EI & 0.0039 & 0.0082 & $-4.885^{* * *}$ \\
\hline INDUS & 0.58 & 0.76 & $-4.080^{* * *}$ \\
\hline OWN & 0.71 & 0.84 & $-3.170^{* * *}$ \\
\hline SIZE & 23.5388 & 23.3613 & $1.219^{* * *}$ \\
\hline LEV & 0.4880 & 0.5628 & -3.886 \\
\hline RD & 0.0141 & 0.0119 & 1.511 \\
\hline GROWTH & 0.2032 & 0.1946 & 0.177 \\
\hline CAPITAL & 2.0909 & 2.2518 & -0.934 \\
\hline N & 283 & 172 & - \\
\hline
\end{tabular}

Notes: $* * * p<0.01$.

suggests a relationship between environmental investment and financial performance in the form of a U. Therefore, $\mathrm{H} 1$ is accepted. To determine the minimum point of the quadratic relationship between environmental investment and financial performance, we choose to consider the regression estimated in column 3 of Table 5. Deriving the function presented in column 3 of Table 5, referring to model (1), to the order we have $\left(\partial \mathrm{ROA}_{\mathrm{i}, \mathrm{t}} / \partial \mathrm{EI}_{\mathrm{i}, \mathrm{t}}\right)=-1.203+90.444 \mathrm{EI}_{\mathrm{i}, \mathrm{t}}=0$, the minimum point of environmental investment being 0.013301 . Therefore, up to 0.013301 , environmental investment can stimulate financial performance.

In model (2), although the coefficient on INDUS*EI ${ }^{2}$ is negative $(\beta=-17.464, \mathrm{t}=-0.930)$, it is not statistically significant at the $5 \%$ level. Therefore, $\mathrm{H} 2$ is not accepted.

Table 8 presents the regression results of models (3) and (4). In model (3), the coefficient on $\mathrm{OWN}^{*} \mathrm{EI}^{2}$ is significant and positive $(\beta=32.836, \mathrm{t}=3.740)$, which supports our H3. That is, company ownership has a positive moderating effect on the relationship between environmental investment and financial performance. In model (4), the coefficient on $\mathrm{AREA}^{*} \mathrm{EI}^{2}$ is positive and significant at the $5 \%$ level. Therefore, $\mathrm{H} 4$ is fully supported.

In addition, we also find that (1) firm size, R\&D intensity and sales growth rate has a significant and positive impact on financial performance, (2) debt ratio negatively affects companies' financial performance, and (3) capital intensity has no impact on financial performance.

\section{Robustness Check}

We conducted a robustness check on models (1)-(4) by using return on investment, measured by dividing operating profit by average total assets, as the dependent variable. The results are similar to our

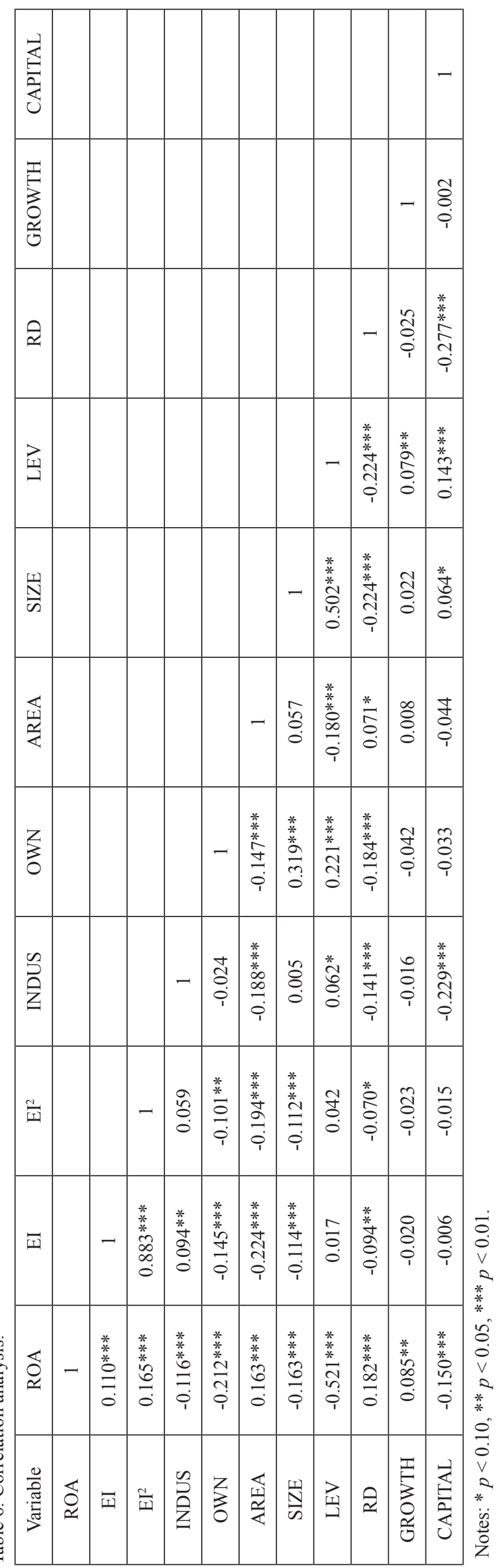


Table 7. Regression results of models (1) and (2).

\begin{tabular}{|c|c|c|c|}
\hline Variable & $\begin{array}{l}\text { Predicted } \\
\text { Sign }\end{array}$ & Model (1) & Model (2) \\
\hline Constant & & $\begin{array}{c}-0.042 \\
(-1.105)\end{array}$ & $\begin{array}{c}-0.030 \\
(-0.768)\end{array}$ \\
\hline EI & $?$ & $\begin{array}{c}-1.203 * * \\
(-2.402)\end{array}$ & $\begin{array}{c}-1.363 * * \\
(-2.385)\end{array}$ \\
\hline $\mathrm{EI}^{2}$ & + & $\begin{array}{c}45.222 * * * \\
(4.852)\end{array}$ & $\begin{array}{c}64.306^{* * *} \\
(2.703)\end{array}$ \\
\hline INDUS & $?$ & & $\begin{array}{l}-0.009 * \\
(-1.799)\end{array}$ \\
\hline INDUS*EI ${ }^{2}$ & $?$ & & $\begin{array}{l}-17.464 \\
(-0.930)\end{array}$ \\
\hline SIZE & + & $\begin{array}{c}0.007 * * * \\
(4.150)\end{array}$ & $\begin{array}{c}0.007 * * * \\
(4.056)\end{array}$ \\
\hline LEV & - & $\begin{array}{c}-0.174 * * * \\
(-13.726)\end{array}$ & $\begin{array}{c}-0.173^{* * *} \\
(-13.570)\end{array}$ \\
\hline $\mathrm{RD}$ & + & $\begin{array}{c}0.333^{* *} \\
(2.130)\end{array}$ & $\begin{array}{l}0.265^{*} \\
(1.669)\end{array}$ \\
\hline GROWTH & + & $\begin{array}{c}0.016 * * * \\
(3.629)\end{array}$ & $\begin{array}{c}0.015^{* * *} \\
(3.545)\end{array}$ \\
\hline CAPITAL & + & $\begin{array}{c}-0.001 \\
(-1.165)\end{array}$ & $\begin{array}{l}-0.002^{*} \\
(-1.815)\end{array}$ \\
\hline YEAR & & Yes & Yes \\
\hline Adj. $\mathrm{R}^{2}$ & & 0.356 & 0.362 \\
\hline $\mathrm{F}$ & & $36.912 * * *$ & $29.623 * * *$ \\
\hline $\mathrm{N}$ & & 455 & 455 \\
\hline
\end{tabular}

Notes: $* p<0.10,{ }^{* *} p<0.05, * * * p<0.01 . t$-values are in parentheses.

previous findings, which suggests that our conclusion is robust.

\section{Discussion}

Our empirical findings allow us to conclude the relationship between environmental investment and financial performance examined in our sample. Opposite to the previous studies [7, 41], we find a U-shaped quadratic relationship between environmental investment and financial performance in China, a developing country. From this, we conclude that up to a certain level of environment investment, environmental investment is a restrictive factor, and that it becomes a positive factor of financial performance beyond that level, which is consistent with Liu and Duan [49]. Formally, financial performance starts to improve when the share of environmental investment exceeds $1.3301 \%$ of total assets. Noteworthy is that around $11 \%$ of Chinese listed companies in our sample dedicate $1.3301 \%$ or more of their assets to environmental investment. Within a limited range, the increase in sales volume due to environmental investment and the decrease in operating costs brought by technological innovation do
Table 8. Regression results of models (3) and (4).

\begin{tabular}{|c|c|c|c|}
\hline Variable & $\begin{array}{l}\text { Predicted } \\
\text { Sign }\end{array}$ & Model (3) & Model (4) \\
\hline Constant & & $\begin{array}{l}-0.066^{*} \\
(-1.741)\end{array}$ & $\begin{array}{c}-0.042 \\
(-1.107)\end{array}$ \\
\hline EI & $?$ & $\begin{array}{c}-1.275^{* *} \\
(-2.580)\end{array}$ & $\begin{array}{c}-2.161 * * * \\
(-3.589)\end{array}$ \\
\hline $\mathrm{EI}^{2}$ & + & $\begin{array}{c}25.665^{* *} \\
(2.382) \\
\end{array}$ & $\begin{array}{c}59.364 * * * \\
(5.764) \\
\end{array}$ \\
\hline OWN & $?$ & $\begin{array}{c}-0.022 * * * \\
(-3.979)\end{array}$ & \\
\hline $\mathrm{OWN} * \mathrm{EI}^{2}$ & $?$ & $\begin{array}{c}32.836^{* * *} \\
(3.740)\end{array}$ & \\
\hline AREA & $?$ & & $\begin{array}{c}0.003 \\
(0.553)\end{array}$ \\
\hline $\mathrm{AREA}^{*} \mathrm{EI}^{2}$ & $?$ & & $\begin{array}{c}103.987 * * * \\
(3.164) \\
\end{array}$ \\
\hline SIZE & + & $\begin{array}{c}0.009 * * * \\
(5.143)\end{array}$ & $\begin{array}{c}0.007 * * * \\
(4.075)\end{array}$ \\
\hline LEV & - & $\begin{array}{c}-0.171 * * * \\
(-13.771) \\
\end{array}$ & $\begin{array}{c}-0.168 * * * \\
(-13.104) \\
\end{array}$ \\
\hline $\mathrm{RD}$ & + & $\begin{array}{c}0.275^{*} \\
(1.777) \\
\end{array}$ & $\begin{array}{l}0.302 * \\
(1.952) \\
\end{array}$ \\
\hline GROWTH & + & $\begin{array}{c}0.015^{* * *} \\
(3.605)\end{array}$ & $\begin{array}{c}0.015^{* * *} \\
(3.531)\end{array}$ \\
\hline CAPITAL & + & $\begin{array}{c}-0.002 \\
(-1.431) \\
\end{array}$ & $\begin{array}{c}-0.002 \\
(-1.450) \\
\end{array}$ \\
\hline YEAR & & Yes & Yes \\
\hline Adj. $\mathrm{R}^{2}$ & & 0.386 & 0.373 \\
\hline $\mathrm{F}$ & & $32.708 * * *$ & $30.955^{* * *}$ \\
\hline $\mathrm{N}$ & & 455 & 455 \\
\hline
\end{tabular}

Notes: $* p<0.10, * * p<0.05, * * * p<0.01 . t$-values are in parentheses.

not cover environmental expenditures. However, when the economic benefits from environmental protection cover these costs, companies will take the initiative to protect the environment.

Conversely, Pekovic et al. [7] confirmed that a firm's performance starts to decline when the share of environmental investment exceeds $16.5 \%$ of total sales. More specifically, there exists an optimal level of environmental investment. Despite the benefits of environmental investment, such an excessive investment requires a large financial investment with some risks, which may reduce a firm's profitability. Fujii et al. [41] concluded that a positive relationship is caused by using cleaner production technology to reduce emissions of toxic chemical substances, while the negative relationship after the turning point is due to excess investment in pollution abatement. Taking listed companies in the coal mining industry, Fan and Wang [63] found that environmental protection investment can obviously promote financial performance due to corporate social responsibility. 
Most Chinese companies usually adopt the end-ofpipe treatment of environmental pollutants with high abatement costs, which in turn reduces its economic performance [10]. In addition, under strict environmental regulations, Chinese companies need to pay a pollution abatement cost that leads to a decrease in profits. In particular, environmentally proactive companies may achieve benefits from environmental investment such as high resource use efficiency that outweighs their costs. Hence, identifying an optimal level of environmental investment can be very useful for the construction and implementation of finely tuned environmental regulations.

We found that $\mathrm{H} 2$ is not accepted. With regard to strict environmental regulation in recent years, Chinese listed companies have begun to realize the importance of environmental protection and make continuous investments in ecological protection regardless of industry. However, the findings of Zhang [64] also showed that environmental investment can bring value to Chinese listed companies in heavy-polluting industries.

In terms of company ownership, $\mathrm{H} 3$ is fully supported. That is, the impact of environmental investment on financial performance in SOEs is higher than that in POEs. SOEs have strong ties with the local government, and environmental investment by SOEs aims to respond to the government environmental policies, which will ensure the effective implementation of these policies.

Finally, we found that a company's environmental investment in China's eastern regions can do more to promote financial performance than in central and western regions. In the case of eastern regions, with the rapid development of the economy, companies have gained benefits from environmental investment and they are more willing to invest more in environmental protection. However, the primary goal of central and western regions is to achieve economic development. In order to ensure the maximization of profits, companies are reluctant to spend much money on environmental protection.

\section{Conclusions}

After more than 50 years of theoretical and empirical research, the results of the impact of environmental investment on firm performance seem to remain inconclusive. Some researchers suggest that environmental investment harms firms, while others claim that it may contribute positively. Therefore, this study examines the environmental-financial performance nexus based on a sample of Chinese listed companies over 5 years (2012 to 2016). The main conclusions of this study are as follows:

(1) The relationship between environmental investment and financial performance can be explained by an almost U-shaped curve. That is, limited environmental investment becomes detrimental to financial performance, and only beyond a point, investing more in greenness will lead to better financial performance.

(2) The impact of environmental investment on financial performance in SOEs is higher than that in POEs.

(3) Corporate environmental investment in eastern regions can do more to promote financial performance than in central and western regions.

To achieve the sustainable development of Chinese listed companies, we make the following implications:

(1) Corporate managers should improve the awareness of environmental protection, clarify social and environmental responsibility, and establish an internal control system of environmental protection, especially in China's central and western regions.

(2) Chinese listed companies should clearly identify the optimal level of environmental investment associated with the benefits from going green and the incurred costs. Meanwhile, they, especially POEs, should increase investment in environmental protection and use cleaner production technology.

(3) Chinese listed companies should build sustainable environmental strategies according to company ownership and their geography for the low-carbon transformation. Meanwhile, the government needs to provide listed companies with financial support to invest for environmental protection.

(4) Chinese listed companies should also voluntarily disclose more environmental information. In addition, the government should carefully check this information and set strict penalties for incorrect information reports.

This study has some limitations. First, we did not examine the effect of environmental investment on financial performance by sector due to sample size. Second, firms' financial performance should be measured in a more systematic way. Therefore, further research on the subject appears warranted.

\section{Acknowledgements}

This research was funded by the Social Science Planning Research Program of Shandong Province (No. 18CKJJ01).

\section{Conflict of Interest}

The authors declare no conflict of interest.

\section{References}

1. JAFFE A.B., PETERSON S.R., PORTNEY P.R., STAVINS R.N. Environmental regulation and the competitiveness of U.S. manufacturing: what does the evidence tell us? Journal of Economic Literature. 33 (1), $132,1995$. 
2. AMBEC S., LANOIE P. Does it pay to be green? A systematic overview. Academy of Management Perspectives. 23 (4), 45, 2008.

3. HORVÁTHOVÁ E. Does environmental performance affect financial performance? A meta-analysis. Ecological Economics. 70 (1), 52, 2010.

4. BARNETT M.L., SALOMON R.M. Does it pay to be really good? Addressing the shape of the relationship between social and financial performance. Strategic Management Journal. 33 (11), 1304, 2012.

5. DIXON-FOWLER H.R., SLATER D.J., JOHNSON J.L., ELLSTRAND A.E., ROMI A.M. Beyond "does it pay to be green?" A meta-analysis of moderators of the CEP-CFP relationship. Journal of Business Ethics. 112 (2), 353, 2013.

6. XU X.L., YANG X.N., ZHAN L., LIU C.K., ZHOU N.D., HU M.M. Examining the relationship between intellectual capital and performance of listed environmental protection companies. Environmental Progress \& Sustainable Energy. 36 (4), 1056, 2017.

7. PEKOVIC S., GROLLEAU G., MZOUGHI N. Environmental investments: Too much of a good thing? International Journal of Production Economics. 197, 297, 2018.

8. RAMANATHAN R., BLACK A., NATH P., MUYLDERMANS L. Impact of environmental regulations on innovation and performance in the UK industrial sector. Management Decision. 48 (10), 1493, 2010.

9. ZHANG, Z.X. Asian energy and environmental policy: Promoting growth while preserving the environment. Energy Policy. 36 (10), 3905, 2008.

10. WANY P., ZHANG J. Ownership structure, corporate environmental investment and financial performance. Journal of Wuhan University of Technology (Information \& Management Engineering). 38 (6), 735, 2016. [In Chinese]

11. LIAO X.C., SHI X.P. Public appeal, environmental regulation and green investment: Evidence from China. Energy Policy. 119, 554, 2018.

12. YANG Y.H., NIU G.H., TANG D.L., ZHU M.J. Does environmental regulation affect the introduction of foreign direct investment in China?--Empirical research based on the spatial Durbin model. Polish Journal of Environmental Studies. 28 (1), 415, 2019.

13. TANG G.P., LI L.H. A Study on Investment Efficiency Evaluation of Enterprise Environmental Protection: The Empirical Evidence Based on China's Capital Market, Dongbei University of Finance \& Economics Press: Dalian, China, 2017.

14. LIN Q.H., CHEN G.Y., DU W.C., NIU H.P. Spillover effect of environmental investment: evidence from panel data at provincial level in China. Frontiers of Environmental Science \& Engineering. 6 (3), 412, 2012.

15. Li C.G., LUO L.Y., XUE Y.D., LIU X.L., ZHANF M.G., ZHANG W.L. Study on the influence of environmental protection investment on GDP in China. Available online: http://download.atlantis-press.com/article/25856625.pdf (accessed on 22 April 2019).

16. BURNETT R.D., HANSEN D.R. Ecoefficiency: Defining a role for environmental cost management. Accounting Organizations and Society. 33 (6), 551, 2008.

17. VARGAS-VARGAS M., MESEGUER-SANTAMARÍA M.L., MONDÉJAR-JIMÉNEZ J., MONDÉJAR-JIMÉNEZ J.A. Environmental protection expenditure for companies: A Spanish regional analysis. International Journal of Environmental Research. 4 (3), 373, 2010.
18. LUNDGREN T., ZHOU W.C. Firm performance and the role of environmental management. Journal of Environmental Management. 203, 330, 2017.

19. KLASSEN R.D., MCLAUGHLIN C.P. The impact of environmental management on firm performance. Management Science. 42 (8), 1199, 1996.

20. KING A., LENOX M. Exploring the locus of profitable pollution reduction. Management Science. 48 (2), 289, 2002.

21. AL-TUWAIJRI S.A., CHRISTENSEN T.E., HUGHES K.E. The relations among environmental disclosure, environmental performance, and economic performance: a simultaneous equations approach. Accounting Organizations and Society. 29 (5-6), 447, 2004.

22. TAMAZIAN A., CHOUSA J.P., VADLAMANNATI K.C. Does higher economic and financial development lead to environmental degradation: Evidence from BRIC countries. Energy Policy. 37 (1), 246, 2009.

23. WALLEY N., WHITEHEAD B. It's not easy being green. Harvard Business Review. 72, 46, 1994.

24. XIAO W.L., GAIMON C., SUBRAMANIAN R., BIEHL $\mathrm{M}$. Investment in environmental process improvement. Production and Operations Management. 28 (2), 407, 2019.

25. ORSATO R.J. Competitive environmental strategies: When does it pay to be green? California Management Review. 48 (2), 127, 2006.

26. SUEYOSHI T., GOTO M. Can environmental investment and expenditure enhance financial performance of US electric utility firms under the clean air act amendment of 1990? Energy Policy. 37 (11), 4819, 2009.

27. HUANF H.Y. Research on influence of environmental protection into business value-A case study of the heavy chemical industry. Master's Dissertation, East China Jiaotong University, Jiangxi, China, 2016.

28. LU L.W.X., TAYLOR, M.E. A study of the relationships among environmental performance, environmental disclosure, and financial performance. Asian Review of Accounting. 26 (1), 107, 2018.

29. MUROVEC N., SLABE-ERKER R., PRODAN I. Determinants of environmental investments: testing the structural model. Journal of Cleaner Production. 37, 265, 2012.

30. SONG H., ZHAO C.G. Does environmental management improve enterprise's value?-An empirical research based on Chinese listed companies. Ecological Indicators. 51, 191, 2015

31. COSTA-CAMPI M.T., GARCÍA-QUEVEDO J., MARTÍNEZ-ROS E. What are the determinants of investment in environmental R \& D? Energy Policy. 104, 455, 2017.

32. MCGUIRE J.B., SUNDGREN A., SCHNEEWEIS T. Corporate social responsibility and firm financial performance. Academy of Management Journal. 31 (4), 854, 1988.

33. BRAGDON J., MARLIN J. Is pollution profitable? Risk Management. 19, 9, 1972.

34. WADDOCK S.A., GRAVES S.B. The corporate social performance-financial performance link. Strategic Management Journal. 18 (4), 303, 1997.

35. ESTY D.C., PORTER M.E. Industrial ecology and competitiveness: strategic implications for the firm. Journal of Industrial Ecology. 2 (1), 35, 1998.

36. BAGUR-FEMENÍAS L., PERRAMON J., AMAT O. Impact of quality and environmental investment on business competitiveness and profitability in small 
service business: the case of travel agencies. Total Quality Management \& Business Excellence. 26 (7-8), 840, 2015.

37. PENG Y., YUE J.G. Corporate environmental investment and financial performance based on investment structure. Environmental Protection Science. 42 (1), 64, 2016. [In Chinese]

38. NISHITANI K., JANNAH N., KANEKO S., HARDINSYAH. Does corporate environmental performance enhance financial performance? An empirical study of Indonesian firms. Environmental Development. 23, 10, 2017.

39. MASOCHA R. Does environmental sustainability impact innovation, ecological and social measures of firm performance of SMEs? Evidence from South Africa. Sustainability. 10 (11), 3855, 2018.

40. BOWMAN E.H., HAIRE M. A strategic posture toward corporate social responsibility. California Management Review. 18 (2), 49, 1975.

41. FUJII H., IWATA K., KANEKO S., MANAGI S. Corporate environmental and economic performance of Japanese manufacturing firms: Empirical study for sustainable development. Business Strategy and the Environment. 22 (3), 187, 2013.

42. GAO M. A study on the impact of corporate environmental protection investment and technology innovation investment on corporate value. Master's Dissertation, China University of Mining and Technology, Jiangsu, China, 2016

43. CHIASSON M.W., DAVIDSON E. Taking industry seriously in information systems research. MIS Quarterly. 29 (4), 591, 2005.

44. TANG G.P., LI L.H. Structure and distribution characteristics of corporate environmental investment: Empirical evidence from A-share listed companies. Journal of Audit \& Economics. 28 (4), 94, 2013. [In Chinese]

45. JIANG Z.Y., WANG Z.J., LI Z.B. The effect of mandatory environmental regulation on innovation performance: Evidence from China. Journal of Cleaner Production. 203, 482, 2018.

46. TANG G.P., LI L.H., WU D.J. Environmental regulation, industry attributes and corporate environmental investment. Accounting Research. 6, 83, 2013. [In Chinese]

47. MONTABON F., ROBERT S., RAM N. An examination of corporate reporting, environmental management practices and firm performance. Journal of Operations Management. 25 (5), 998, 2007.

48. TIAN Z.L., DENG X.M. The determinants of corporate political strategy: An empirical examination in China. Nankai Business Review. 10 (1), 81, 2007 [In Chinese].

49. LIU W.S., DUAN S.S. U-shaped relationship between company environmental performance and financial performance-An empirical research based on the manufacturing industry listed companies in China. East China Economic Management. 27 (11), 111, 2013 [In Chinese].
50. WU A.H. The signal effect of government R\&D subsidies in China: Does ownership matter? Technological Forecasting and Social Change. 117, 339, 2017.

51. 51. DENG J.P., ZENG Y. Can political connection improve the performance of private enterprises. China Industrial Economics. 251 (2), 98, 2009 [In Chinese].

52. LI H.X. Research on relationship between environmental performance and financial performance of the mining enterprises in our country. Master's Dissertation, China University of Geosciences, Beijing, China, 2016.

53. YANG X., WANG L.J. Comparison of regional relationship between environmental performance and financial performance: Evidence from Chinese listed companies in heavy pollution industries. Human Geography. 31 (5), 155, 2016 [In Chinese].

54. ZHANG Y. Research on the correlation between environmental performance and financial performance in heavy-polluted industry. Master's Dissertation, North China University of Technology, Beijing, China, 2018.

55. HART S.L., AHUJA G. Does it pay to be green? An empirical examination of the relationship between emission reduction and firm performance. Business Strategy and the Environment. 5 (1), 30, 1996.

56. RUSSO M.V., FOUTS P.A. A resource-based perspective on corporate environmental performance and profitability. Academy of Management Journal. 40 (3), 534, 1997.

57. ELSAYED K., PATON D. The impact of environmental performance on firm performance: static and dynamic panel data evidence. Structural Change and Economic Dynamics. 16 (3), 395, 2005.

58. NAKAMURA E. Does environmental investment really contribute to firm performance? An empirical analysis using Japanese firms. Eurasian Business Review. 1 (2), 91, 2011.

59. LIN Q.Y. Research on the influence of enterprise environmental protection investment on enterprise performance. Master's Dissertation, Anhui University of Technology, Anhui, China, 2016.

60. WEI F., DING B., KONG Y. Female directors and corporate social responsibility: Evidence from the environmental investment of Chinese listed companies. Sustainability. 9 (12), 2292, 2017.

61. KING A.A., LENOX M.J. Does it really pay to be green? An empirical study of firm environmental and financial performance. Journal of Industrial Ecology. 5 (1), 105, 2001.

62. NUNES P.M., SERRASQUEIRO Z., LEITÃO J. Is there a linear relationship between R\&D intensity and growth? Empirical evidence of non-high-tech vs. high-tech SMEs. Research Policy. 41 (1), 36, 2012.

63. FAN B.X., WANG W.J. Research on the synergetic effect of environmental protection and green technology innovation on financial performance in coal enterprises. Chongqing Social Sciences. 6, 70, 2019. [In Chinese]

64. ZHANG J.J. Environmental protection investment and market value. Modern Economy. 10 (2), 399, 2019. 
